\title{
The prevalence of antimicrobial resistance in clinical isolates from Gulf Corporation Council countries
}

\author{
Mahmoud Aly ${ }^{1}$ and Hanan H. Balkhy ${ }^{1,2,3^{*}}$
}

\begin{abstract}
Background: The burden of antimicrobial resistance worldwide is substantial and is likely to grow. Many factors play a role in the emergence of resistance. These resistance mechanisms may be encoded on transferable genes, which facilitate the spread of resistance between bacterial strains of the same and/or different species. Other resistance mechanisms may be due to alterations in the chromosomal DNA which enables the bacteria to withstand the environment and multiply. Many, if not most, of the Gulf Corporation Council (GCC) countries do not have clear guidelines for antimicrobial use, and lack policies for restricting and auditing antimicrobial prescriptions.
\end{abstract}

Objective: The aim of this study is to review the prevalence of antibiotic resistance in GCC countries and explore the reasons for antibiotic resistance in the region.

Methodology: The PubMed database was searched using the following key words: antimicrobial resistance, antibiotic stewardship, prevalence, epidemiology, mechanism of resistance, and GCC country (Saudi Arabia, Qatar, Bahrain, Kuwait, Oman, and United Arab Emirates).

Results: From January 1990 through April 2011, there were 45 articles published reviewing antibiotic resistance in the GCC countries. Among all the GCC countries, 37,295 bacterial isolates were studied for antimicrobial resistance. The most prevalent microorganism was Escherichia coli (10,073/44\%), followed by Klebsiella pneumoniae (4,709/20\%), Pseudomonas aeruginosa (4,287/18.7\%), MRSA (1,216/5.4\%), Acinetobacter (1,061/5\%), with C. difficile and Enterococcus representing less than $1 \%$.

Conclusion: In the last 2 decades, E. coli followed by Klebsiella pneumoniae were the most prevalent reported microorganisms by GCC countries with resistance data.

Keywords: Antibiotics/antimicrobials, Resistance, GCC, (Saudi Arabia, Qatar, Bahrain, Kuwait, Oman, and United Arab Emirates) Gram negative, Gram positive, Anaerobes, Pathogens, Infection, Resistance mechanisms, Molecular typing

\section{Findings}

The burden of antimicrobial resistance worldwide is substantial and is likely to grow [1]. Furthermore, many factors play a role in the emergence of resistance such as from poor utilization of antimicrobial agents, transmission of resistant bacteria from patient to patient and from Health-care workers (HCWs) to patients and vice versa, lack of guidelines for appropriate and judicious

\footnotetext{
* Correspondence: balkhyh@ngha.med.sa

${ }^{1}$ King Abdullah International Medical Research Center, Riyadh, Saudi Arabia ${ }^{2}$ Infection Prevention and Control Department, King Abdulaziz Medical City, Riyadh, Saudi Arabia

Full list of author information is available at the end of the article
}

use of antimicrobial agents and lack of easy-to-use auditing tools for restriction. In addition, there is clear misuse of antimicrobial agents in the animal industry, and most agents are the same agents used in humans. Further, there are few antimicrobial agents in the pipeline of production, leaving clinicians with minimal tools to combat these infections. All these factors, together, have led to the inevitable emergence and rise of resistance.

Bacteria develop antimicrobial resistance through many mechanisms including mutations in penicillin binding proteins, efflux mechanisms, alterations in outer membrane proteins and the production of hydrolyzing enzymes such as extended spectrum $\beta$ lactamase (ESBL) and

\section{Biomed Central}


carbapenemases [2]. These resistance mechanisms may be encoded on transferable genes which facilitate the spread between bacteria of the same species and between different species. Other resistance mechanisms may be due to alterations in the chromosomal DNA which enables the bacteria to withstand the harsh environment and multiply.

Many, if not most, of the Gulf Corporation Council (GCC) countries do not have clear guidelines for antimicrobial use and lack policies for restricting and auditing antimicrobial prescriptions. There are no guidelines for the use of antimicrobials in the animal industries either. Thus, it is not surprising that antimicrobial resistance has emerged in these countries [3]. There are few reports studying prevalence rates of resistance among the different pathogens and mechanisms of resistance at the national level.

\section{Objective}

The aim of this study is to review the prevalence of antibiotic resistance in GCC countries and explore the reasons for antibiotic resistance in the region.

\section{Methodology}

The PubMed database was searched using the following key words: antimicrobial resistance, antibiotic stewardship, prevalence, epidemiology, mechanism of resistance, and GCC country (Saudi Arabia, Qatar, Bahrain, Kuwait, Oman, and United Arab Emirates). Specific organisms were searched for Gram negative bacteria: Acinetobacter, Klebsiella pneumoniae, Pseudomonas aeruginosa and Escherichia coli, and for Gram positive bacteria: Methicillin-resistant Staphylococcus aureus (MRSA), VancomycinResistant Enterococci (VRE) and Clostridium difficile (C. difficile). To identify the resistance mechanisms, these studies followed routine laboratory diagnostics and surveillance testing.

\section{Statistical analysis}

Statistical data were generated and analyzed using the statistical software SPSS version 19. Descriptive statistics were calculated and the weighted mean was estimated using the estimated marginal mean function in SPSS.
Data were expressed as number $(n)$ and percentage (\%); Table 1. Records of the total numbers of clinical isolates were grouped based on their country and species according to their gram staining classification; Table 2. Data were represented as total number of isolates $(n)$ and their percentage (\%).

\section{Results}

Between 1990 and April 2011, there were 45 articles published reviewing antibiotic resistance in GCC countries. Eleven articles were excluded because of their low number of isolates $(n<100)$ [35-45]. Thirty four articles were analyzed as they contained national data. Among all the GCC countries, 37,295 bacterial isolates were studied for antimicrobial resistance. The isolates were distributed as follows: Bahrain (2,841/7.6\%), Kuwait (20,339/54.5\%), Oman (882/2.4\%), Qatar (570/1.5\%), Saudi Arabia (12,174/32.6\%) and UAE (491/1.3\%); Figure 1.

The most prevalent microorganism was Escherichia coli (10073, 44\%), followed by Klebsiella pneumoniae (4,709: 20\%), Pseudomonas aeruginosa (4,287/18.7\%), MRSA (1,216: 5.4\%), Acinetobacter (1,061/5\%), with $C$. difficile and Enterococcus representing less than 1\%.

Some national isolates showed high resistance than others. In Qatar, Khan, Elshafie et al. 2010, reported the occurrence of resistant Gram-negative organisms in $63.1 \%$ of bacteremia patients $(n=452)$ with the following prevalences: ESBL-resistant $E$ coli (34\%), followed by Klebsiella spp. (39/13.7\%) and finally Pseudomonas aeruginosa (7.4\%) [18]. Shigidi and his group found that Staphylococcus was most prevalent (29\%), followed by $E$ coli (9\%) and Pseudomonas aeruginosa was the least resistant with only $3 \%$ prevalence among dialysis patients in 2010 [7]. Their results, however, should be considered with caution because they tested relatively low number of cases $(n=118)$. A trend of MRSA infection in the burn center of the Sultanate of Oman was reported [16]. ESBL phenotypes were detected in more than $21 \%$ of the total isolates indicating their correlation with the resistance.

Table 1 The data of selected clinical isolates reported by GCC countries

\begin{tabular}{llllllll}
\hline Country & Population & Population $\%$ & Reports $(\boldsymbol{n})$ & Reports\% & Isolates $(\boldsymbol{n})$ & Isolates\% & References \\
\hline Bahrain & $1,106,509$ & $2.9 \%$ & 3 & $9.1 \%$ & 2841 & $7.6 \%$ & {$[4-6]$} \\
Kuwait & $2,583,020$ & $6.7 \%$ & 9 & $27.3 \%$ & 20339 & $54.5 \%$ & {$[7-15]$} \\
Oman & $3,173,917$ & $8.2 \%$ & 3 & $9.1 \%$ & 882 & $2.4 \%$ & {$[8,16,17]$} \\
Qatar & $1,608,903$ & $4.2 \%$ & 2 & $6.1 \%$ & 570 & $1.5 \%$ & {$[7,18]$} \\
Saudi Arabia & $25,373,512$ & $65.7 \%$ & 14 & $42.4 \%$ & 12174 & $32.6 \%$ & {$[19-32]$} \\
UAE & $4,765,000$ & $12.3 \%$ & 2 & $6.1 \%$ & 491 & $1.3 \%$ & {$[33,34]$} \\
GCC total & $38,610,861$ & $100.0 \%$ & 33 & $100.0 \%$ & 37295 & $100.0 \%$ & $n=33$ articles \\
\hline
\end{tabular}


Table 2 The prevalence of resistant pathogens in clinical isolates from GCC countries

\begin{tabular}{|c|c|c|c|c|c|c|c|c|}
\hline \multirow[t]{2}{*}{ Country } & \multicolumn{4}{|l|}{ Gram Negative } & \multicolumn{4}{|c|}{ Gram Positive } \\
\hline & Acinetobacter & Escherichiacoli & $\begin{array}{l}\begin{array}{l}\text { Klebsiella } \\
\text { pneumoniae }\end{array} \\
\end{array}$ & $\begin{array}{l}\text { Pseudomonas } \\
\text { aeruginosa }\end{array}$ & $\begin{array}{l}\text { Clostridium } \\
\text { difficile }\end{array}$ & Enterococcus & MRSA & $\begin{array}{l}\text { Streptococcus } \\
\text { pneumoniae }\end{array}$ \\
\hline Bahrain & $N . R$ & $14.0 \%$ & $13.9 \%$ & N.R & N.R & $76.5 \%$ & $8.5 \%$ & N.R \\
\hline Kuwait & $16.7 \%$ & $77.0 \%$ & $36.2 \%$ & $2.6 \%$ & $70.0 \%$ & N.R & $3.3 \%$ & $66.3 \%$ \\
\hline Oman & N.R & N.R & $0.1 \%$ & $0.3 \%$ & $0.0 \%$ & N.R & $58.3 \%$ & N.R \\
\hline Qatar & N.R & $1.1 \%$ & $0.8 \%$ & $0.6 \%$ & N.R & N.R & N.R & N.R \\
\hline Saudi Arabia & $83.3 \%$ & $7.6 \%$ & $48.3 \%$ & $92.3 \%$ & $30.0 \%$ & $23.5 \%$ & $29.9 \%$ & $30.7 \%$ \\
\hline UAE & N.R & $0.3 \%$ & $0.7 \%$ & $4.2 \%$ & N.R & N.R & N.R & $3.0 \%$ \\
\hline
\end{tabular}

GCC = Gulf Corporation Council; N.R = not reported; MRSA = methicillin resistant Staphylococcus aureus; UAE = United Arab Emirates.

\section{Conclusions}

The geographical distributions of the resistance isolates during (1990-2011) in the gulf region were shown in Figure 1. The most prevalent reported microorganism with resistance data reported by GCC countries in the last 2 decades was E. coli, followed by Klebsiella pneumoniae and others. Multiple ESBL genes were identified, however, no carbapenamases were present and thus further work to identify the mechanism of resistance, such as c-di-GMP and others, is required. Many hospitals within the Kingdom have identified carbapenem resistance among enterobacteriaceae, and Oman has reported NDM-1 in Klebsiella isolates in 2010[17]. From our experience at KAMC in Riyadh, a 1000 bed hospital, we have identified for the first time carbapenem-resistant Klebsiella pneumoniae which led to an outbreak stemming from the adult ICU [46].

The emergence of antimicrobial resistance in GCC countries might have occurred for several reasons. One is the readily available broad spectrum antibiotics, such as $3^{\text {rd }}$ and

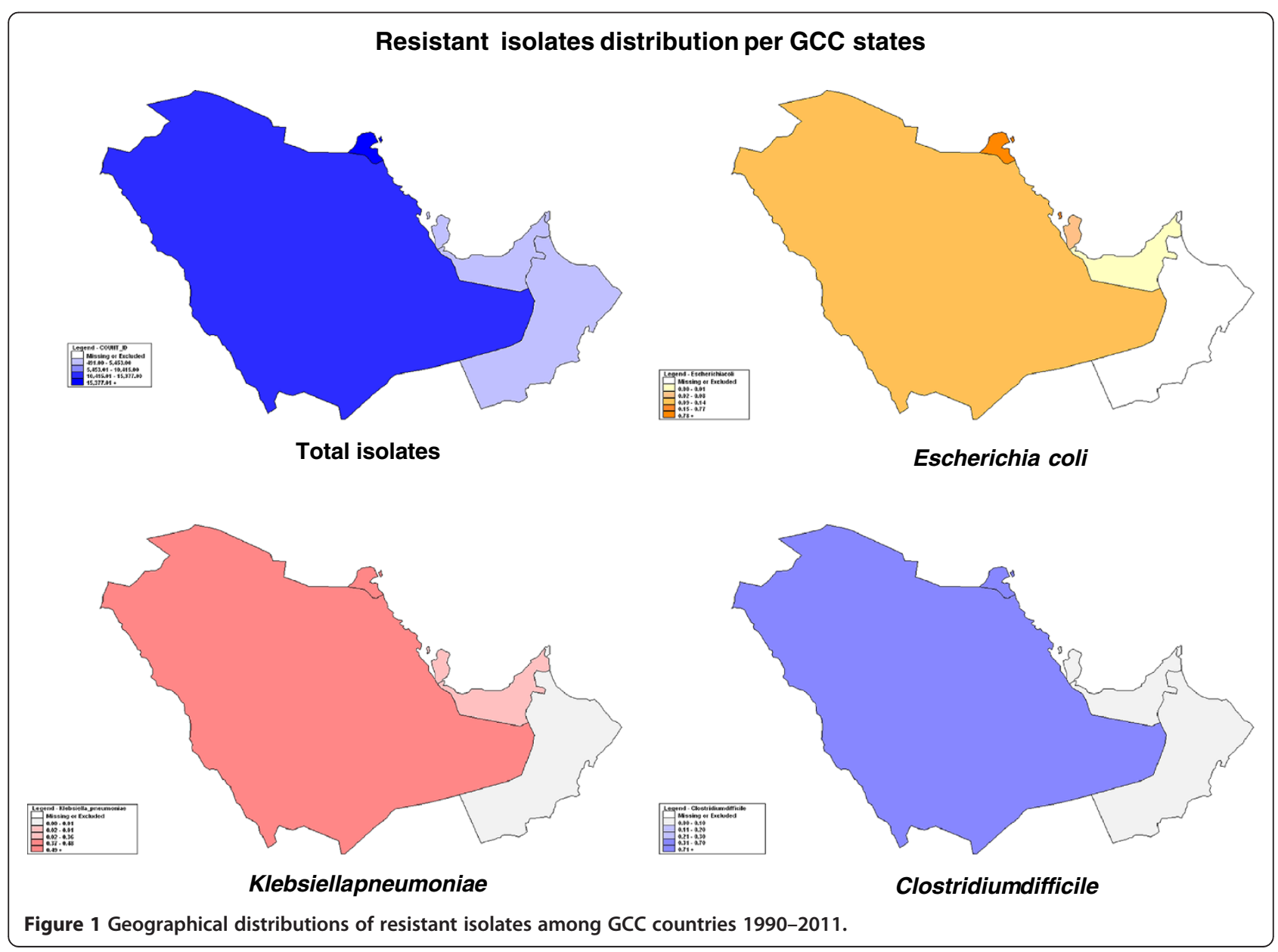


$4^{\text {th }}$ generation cephalosporins, quinolones and carbapenems in the healthcare settings. Most GCC countries lack the presence of antimicrobial stewardship programs, especially in the inpatient setting where broad spectrum antimicrobial agents are used. Most hospitals' architectural designs are old and many harbor 2 and 4 bedded rooms, which do not allow for proper isolation of infected and colonized patients with multi-drug resistant organisms. There a lack of strong infection control programs, properly trained infectious disease specialists and clinical pharmacists in the field of infectious diseases. In advanced healthcare systems, integrated computerized programs allowing for the restriction of antimicrobial agents and providing decision-assisted physician orders have proven to be helpful in controlling the use of antibiotics. Such alternatives may be expensive and not suitable for all healthcare settings. Further, highly skilled and dedicated information technology personnel are needed to support these systems. Finally, the lack of clinical pharmacists and infectious disease specialists may be a major contributor to the current emergence of resistance. Multidisciplinary teams including: infectious diseases, intensivists, surgeons, pulmonologists and emergency room specialists and clinical pharmacists may be needed to enhance utilization of antibiotics and play an important role in recommending the appropriate antimicrobial regimens and proper guidance on treatment and de-escalation.

\section{Competing interests}

The authors declare that they have no competing interests.

\section{Authors' contributions}

MA: acquisition, analysis and interpretation of data; drafting the manuscript. HB: analysis and interpretation of data; drafting the manuscript. All authors read and approved the final manuscript.

\section{Author details}

${ }^{1}$ King Abdullah International Medical Research Center, Riyadh, Saudi Arabia. ${ }^{2}$ Infection Prevention and Control Department, King Abdulaziz Medical City, Riyadh, Saudi Arabia. ${ }^{3}$ King Saud bin Abdulaziz University for Health Sciences, Riyadh, Saudi Arabia.

Received: 28 March 2012 Accepted: 19 July 2012

Published: 19 July 2012

\section{References}

1. WHO: World Health Day - 7 April 2011"Antimicrobial resistance: no action today, no cure tomorrow". In Book World Health Day - 7 April 2011 "Antimicrobial resistance: no action today, no cure tomorrow" (Editor ed.^eds.). City; 2011

2. Paterson DL, Bonomo RA: Extended-spectrum beta-lactamases: a clinical update. Clin Microbiol Rev 2005, 18:657-686.

3. Memish ZA, Ahmed QA, Arabi YM, Shibl AM, Niederman MS: Microbiology of community-acquired pneumonia in the Gulf Corporation Council states. J Chemother 2007, 19(Suppl 1):17-23.

4. Bindayna KM, Senok AC, Jamsheer AE: Prevalence of extended-spectrum beta-lactamase-producing Enterobacteriaceae in Bahrain. $J$ Infect Public Health 2009, 2:129-135.

5. Udo EE, Panigrahi D, Jamsheer AE: Molecular typing of methicillinresistant Staphylococcus aureus isolated in a Bahrain hospital. Med Princ Pract 2008, 17:308-314.
6. Wallace MR, Johnson AP, Daniel M, Malde M, Yousif AA: Sequential emergence of multi-resistant Klebsiella pneumoniae in Bahrain. $J$ Hosp Infect 1995, 31:247-252.

7. Shigidi MM, Fituri OM, Chandy SK, Asim M, Al Malki HA, Rashed AH: Microbial spectrum and outcome of peritoneal dialysis related peritonitis in Qatar. Saudi J Kidney Dis Transp/ 2010, 21:168-173.

8. Al Benwan K, Al Sweih N, Rotimi VO: Etiology and antibiotic susceptibility patterns of community- and hospital-acquired urinary tract infections in a general hospital in Kuwait. Med Princ Pract 2010, 19:440-446.

9. Dashti AA, Jadaon MM, Amyes SG: Retrospective study of an outbreak in a Kuwaiti hospital of multidrug-resistant Klebsiella pneumoniae possessing the new SHV-112 extended-spectrum beta-lactamase. J Chemother 2010, 22:335-338.

10. Jamal W, Rotimi VO, Brazier J, Duerden Bl: Analysis of prevalence, risk factors and molecular epidemiology of Clostridium difficile infection in Kuwait over a 3-year period. Anaerobe 2010, 16:560-565.

11. Jamal WY, El-Din K, Rotimi VO, Chugh TD: An analysis of hospital-acquired bacteraemia in intensive care unit patients in a university hospital in Kuwait. J Hosp Infect 1999, 43:49-56.

12. Johny M, Babelly M, Al-Obaid I, Al-Benwan K, Udo EE: Antimicrobial resistance in clinical isolates of Streptococcus pneumoniae in a tertiary hospital in Kuwait, 1997-2007: implications for empiric therapy. J Infect Public Health 2010, 3:6066.

13. Mokaddas EM, Abdulla AA, Shati S, Rotimi VO: The technical aspects and clinical significance of detecting extended-spectrum beta-lactamaseproducing Enterobacteriaceae at a tertiary-care hospital in Kuwait. $J$ Chemother 2008, 20:445-451.

14. Rotimi VO, Al-Sweih NA, Feteih J: The prevalence and antibiotic susceptibility pattern of gram-negative bacterial isolates in two ICUs in Saudi Arabia and Kuwait. Diagn Microbiol Infect Dis 1998, 30:53-59.

15. Rotimi VO, Mokaddas EM, Jamal WY, Verghese TL, El-Din K, Junaid TA: Hospital-acquired Clostridium difficile infection amongst ICU and burn patients in Kuwait. Med Princ Pract 2002, 11:23-28.

16. Prasanna M, Thomas C: A profile of methicillin resistant Staphylococcus aureus infection in the burn center of the Sultanate of Oman. Burns 1998, 24:631-636.

17. Poirel L, Al Maskari Z, Al Rashdi F, Bernabeu S, Nordmann P: NDM-1producing Klebsiella pneumoniae isolated in the Sultanate of Oman. J Antimicrob Chemother 2011, 66:304-306.

18. Khan FY, Elshafie SS, Almaslamani M, Abu-Khattab M, El Hiday AH, Errayes M, Almaslamani E: Epidemiology of bacteraemia in Hamad general hospital, Qatar: a one year hospital-based study. Travel Med Infect Dis 2010, 8:377387.

19. Ahmad S, Al-Juaid NF, Alenzi FQ, Mattar EH, Bakheet Oel S: Prevalence, antibiotic susceptibility pattern and production of extended-spectrum beta-lactamases amongst clinical isolates of Klebsiella pneumoniae at Armed Forces Hospital in Saudi Arabia. J Coll Physicians Surg Pak 2009, 19:264-265.

20. Akhter J, Frayha HH, Qadri SM: Current status and changing trends of antimicrobial resistance in Saudi Arabia. J Med Liban 2000, 48:227-232.

21. Al Johani SM, Akhter J, Balkhy H, El-Saed A, Younan M, Memish Z: Prevalence of antimicrobial resistance among gram-negative isolates in an adult intensive care unit at a tertiary care center in Saudi Arabia. Ann Saudi Med 2010, 30:364-369.

22. Al-Tawfiq JA, Abed MS: Prevalence and antimicrobial resistance of health care associated bloodstream infections at a general hospital in Saudi Arabia. Saudi Med J 2009, 30:1213-1218.

23. Al-Tawfiq JA, Abed MS: Clostridium difficile-associated disease among patients in Dhahran, Saudi Arabia. Travel Med Infect Dis 2010, 8:373-376.

24. Al-Tawfiq JA, Antony A: Antimicrobial resistance of Klebsiella pneumoniae in a Saudi Arabian hospital: results of a 6-year surveillance study, 1998-2003. J Infect Chemother 2007, 13:230-234.

25. Asghar AH, Faidah HS: Frequency and antimicrobial susceptibility of gram-negative bacteria isolated from 2 hospitals in Makkah, Saudi Arabia. Saudi Med J 2009, 30:1017-1023.

26. Babay HA: Antimicrobial resistance among clinical isolates of Pseudomonas aeruginosa from patients in a teaching hospital, Riyadh, Saudi Arabia, 2001-2005. Jpn J Infect Dis 2007, 60:123-125.

27. Balkhy HH, Cunningham G, Chew FK, Francis C, Al Nakhli DJ, Almuneef MA, Memish ZA: Hospital- and community-acquired infections: a point prevalence and risk factors survey in a tertiary care center in Saudi Arabia. Int J Infect Dis 2006, 10:326-333. 
28. Balkhy HH, Memish ZA, Shibl A, Elbashier A, Osoba A: In vitro activity of quinolones against $\mathrm{S}$. pneumoniae, $\mathrm{H}$. influenzae and $\mathrm{M}$. catarrhalis in Saudi Arabia. East Mediterr Health J 2005, 11:36-44.

29. Bilal NE, Gedebou M: Staphylococcus aureus as a paradigm of a persistent problem of bacterial multiple antibiotic resistance in Abha, Saudi Arabia. East Mediterr Health J 2000, 6:948-954

30. Fouda SI, Kadry AA, Shibl AM: Beta-lactam and macrolide resistance and serotype distribution among Streptococcus pneumoniae isolates from Saudi Arabia. J Chemother 2004, 16:517-523.

31. Memish ZA, Balkhy HH, Shibl AM, Barrozo CP, Gray GC: Streptococcus pneumoniae in Saudi Arabia: antibiotic resistance and serotypes of recent clinical isolates. Int J Antimicrob Agents 2004, 23:32-38.

32. Shibl AM, Al Rasheed AM, Elbashier AM, Osoba AO: Penicillin-resistant and -intermediate Streptococcus pneumoniae in Saudi Arabia. J Chemother 2000, 12:134-137.

33. Al-Muhairi S, Zoubeidi T, Ellis M, Nicholls MG, Safa W, Joseph J: Demographics and microbiological profile of pneumonia in United Arab Emirates. Monaldi Arch Chest Dis 2006, 65:13-18.

34. Al-Zarouni M, Senok A, Rashid F, Al-Jesmi SM, Panigrahi D: Prevalence and antimicrobial susceptibility pattern of extended-spectrumbetalactamase-producing Enterobacteriaceae in the United Arab Emirates. Med Princ Pract 2008, 17:32-36.

35. Aly NY, Al-Mousa HH, Al Asar el SM: Nosocomial infections in a medical-surgical intensive care unit. Med Princ Pract 2008, 17:373-377.

36. Babay HA, Twum-Danso K, Kambal AM, Al-Otaibi FE: Bloodstream infections in pediatric patients. Saudi Med J 2005, 26:1555-1561.

37. Bang RL, Gang RK, Sanyal SC, Mokaddas E, Ebrahim MK: Burn septicaemia: an analysis of 79 patients. Burns 1998, 24:354-361

38. Bukharie HA, Abdelhadi MS, Saeed IA, Rubaish AM, Larbi EB: Emergence of methicillin-resistant Staphylococcus aureus as a community pathogen. Diagn Microbiol Infect Dis 2001, 40:1-4.

39. Gang RK, Bang RL, Sanyal SC, Mokaddas E, Lari AR: Pseudomonas aeruginosa septicaemia in burns. Burns 1999, 25:611-616.

40. Jumaa PA, Neringer R: A survey of antimicrobial resistance in a tertiary referral hospital in the United Arab Emirates. J Chemother 2005, 17:376-379.

41. Kader AA, Kumar A: Prevalence and antimicrobial susceptibility of extended-spectrum beta-lactamase-producing Escherichia coli and Klebsiella pneumoniae in a general hospital. Ann Saudi Med 2005, 25:239-242

42. Narchi $\mathrm{H}, \mathrm{Al}-\mathrm{Hamdan} \mathrm{MA}$ : Antibiotic resistance trends in paediatric community-acquired first urinary tract infections in the United Arab Emirates. East Mediterr Health J 2010, 16:45-50.

43. Nzeako BC, Al Daughari H, Al Lamki Z, Al Rawas O: Nature of bacteria found on some wards in Sultan Qaboos University Hospital, Oman. Br J Biomed Sci 2006, 63:55-58.

44. Shamseldin el Shafie S, Smith W, Donnelly G: An outbreak of gentamicin-resistant Klebsiella pneumoniae in a neonatal ward. Cent Eur J Public Health 1995, 3:129-131.

45. Udo EE, Al-Sweih N, Phillips OA, Chugh TD: Species prevalence and antibacterial resistance of enterococci isolated in Kuwait hospitals. $J$ Med Microbiol 2003, 52:163-168.

46. Balkhy H, El-Saed A, Al Johani S, Tayeb H, Al-Qahtani A, Alahdal M, Sallah M, Alothman A, Alarabi Y: Epidemiology of the first outbreak of carbapenemresistant Klebsiella pneumoniae in Saudi Arabia. BMC Proceedings 2011, 5:P295.

doi:10.1186/2047-2994-1-26

Cite this article as: Aly and Balkhy: The prevalence of antimicrobial resistance in clinical isolates from Gulf Corporation Council countries. Antimicrobial Resistance and Infection Control 2012 1:26.

\section{Submit your next manuscript to BioMed Central and take full advantage of:}

- Convenient online submission

- Thorough peer review

- No space constraints or color figure charges

- Immediate publication on acceptance

- Inclusion in PubMed, CAS, Scopus and Google Scholar

- Research which is freely available for redistribution

Submit your manuscript at www.biomedcentral.com/submit 